\title{
Overcoming barriers to the implementation of alternative fuels for road transport in Europe
}

\author{
Thérèse Steenberghen , Elena López \\ SADL, K.U. Leuven R\&D, Celestijnenlaan 200E, B-300I Heverlee, Belgium \\ TRANSyT-UPM, Universidad Politécnica de Madrid, Av. Professor Aranguren, sin, ETISCCP, 28040 Madrid, Spain
}

\begin{abstract}
The success of implementing alternative fuels for road transport depends on their cost, performance and reliability. This paper focuses on the use of natural gas and LPG, hydrogen and biofuels in Europe. A brief presentation is given of their technical development status, their market potential, and barriers to their implementation in various market segments. Some market barriers are common to many new technologies, and can be overcome through adequate policy measures at European level. Generally, a combination of policies is required, and a number of supporting measures increase their effectiveness. The following policies affecting energy use in transport are discussed: market incentives, policies targeting technology and vehicle efficiency, and overall system improvement.
\end{abstract}

Keywords: Market incentives; Barriers to implementation; Alternative fuels; Transport; Energy policy

\section{Introduction}

Security of energy supply, environmental sustainability and competitiveness are three main objectives of the European Union (EU) Energy policy . To reconcile these highly interrelated objectives, integrated strategies are needed to invest in cleaner and more sustainable energy. These require strong support and guidance from the EU and national governments to take advantage of the synergies and deal with the inevitable trade-offs between the aforementioned objectives.

Transport has become the largest consumer of energy at the EU level, accounting for over $30 \%$ or final energy consumption in the EU-25 |. The share of this energy imported from third countries is increasing; with continuation of the current trends, by 2030 the EU will be dependent on imports for $90 \%$ of its oil requirements and $80 \%$ for gas. Given the recent steep increases in oil and gas prices, along with the risk of potential disruptions due to the geopolitical instability of some major exporting countries, this oil dependence constitutes a threat for the Eus' competitiveness.

Recent decades have witnessed an increased concern of the environmental effects of transport, reflected in an upsurge of policy instruments to handle these negative environmental external effects and to monitor their evolution, with mechanisms such as the TERM Reports . It appears that despite the important efforts devoted to environmental abatement policies, the increased transport demand is outstripping the rate of improvement in environmental technology for transport

. The result is a significant increase in Green House Gas (GHG) emissions from transport, while emissions from energy production, services and industry sectors all decreased in the same period. This trend threatens European progress towards its international commitments, such as the Kyoto targets and the proposals by the EU Council for further emission reductions for developed countries beyond the Kyoto Protocol period (2008-2012) .

Although energy-related emissions from the transport sector have decreased steadily since 1990 , largely due to 
increasingly strict emission standards for different transport modes and fuel switching, further emission reductions are required. The proposed Thematic Strategy on Air Pollution (2005) recognises that the air quality in mega cities does not yet meet the limit values set by European regulation and still has a major negative impact on human health

These issues are strong arguments to enhance the use of cleaner and energy effective technologies and alternative fuels. However, when the life cycle assessment (LCA) thinking is taken into account, important trade-offs between emissions, costs and energy efficiency of the different technologies and alternative fuels appear. Moreover, some technologies may have opposite effects on different environmental issues

A technical assessment of possible synergies and tradeoffs would draw a more realistic picture and may therefore constitute a valuable tool and to support decision-makers

The market penetrations of new technologies and fuels have to tackle serious economic, technological and institutional barriers . A clear government leadership is needed to promote the implementation of these innovations, including public policy and collaboration with the private sector, so that energy-efficient solutions become financially attractive both for enterprises and consumers

The potential benefits of introduction of new technologies in transport are significant. The EU could achieve a $20 \%$ reduction of its energy consumption compared to the projections for 2020 on a cost-effective basis if today's most advanced technologies were fully integrated in the market . In this line, recent decades have witnessed the upsurge of a wide variety of policy options to overcome barriers for the market penetration of transport-related technology developments

. However, the assessment of their effectiveness on final energy consumption constitutes an underdeveloped field for researchers. Models aimed at simulating policies and measures could then be translated into policy recommendations for decision-makers

This paper investigates existing barriers for the implementation of alternative fuels in the transport sector in Europe, and existing policy measures to overcome these barriers. First, an analytical framework of political, socio-economic and technological environments affecting energy use in the transport system is presented. Then leading developments concerning the use of alternative fuels in transport are discussed, along with their market position, their future potential and barriers to implementation. The following section discusses European policy options to overcome these barriers.

\section{Political, socio-economic and technological environments affecting the use of energy in the transport sector}

In order to understand barriers to the implementation of alternative fuels in the transport sector and policies to overcome these barriers, the relationship between different environments affecting energy use in transport is presented (Fig. 1). Energy use in transport is examined as a separate system, interactions with other energy using systems are not considered.

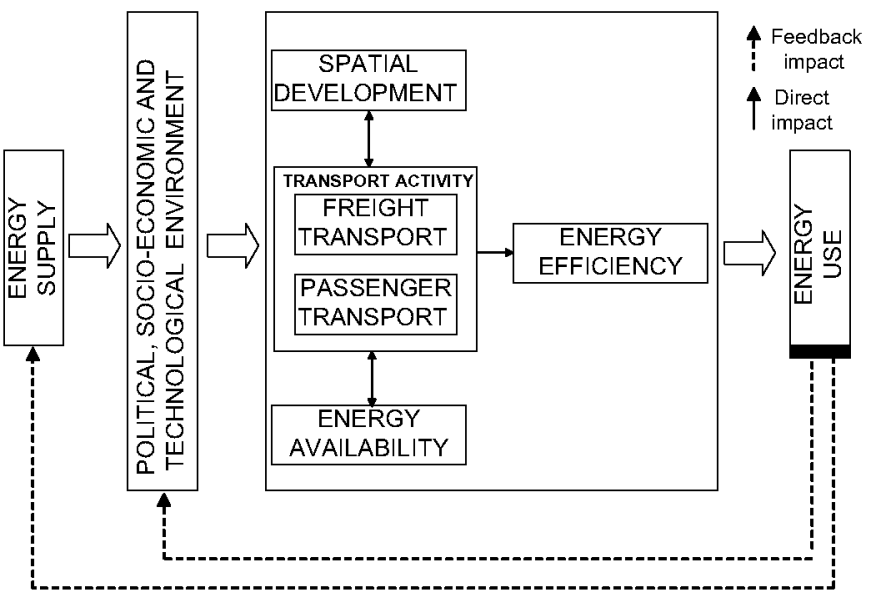

Fig. 1. Conceptual approach and relationships between the different drivers affecting energy use.

The primary drivers of the system are presented at the left side of the diagram. Energy supply, defined as the world-level existence of energy resources in varied forms, in sufficient quantities, and at reasonable prices, affects energy use in transport through the political, socio-economic and technological environment. These environments affect transport activity directly, and indirectly, through complex interactions between spatial development and transport activity; and through their impact on energy availability for transport activities.

Energy use in transport also indirectly affects the energy supply and the political, socio-economic and technological environment, i.e. the increase in transport demand may in the future threaten the security of energy supply and affect international fossil fuel prices, even more with the impending increase of energy demand in highly populated countries, such as China and India.

The political, socio-economic and technological environment affects the volume of transport activity, measured in terms of passenger-km (pass-km) and tons $-\mathrm{km}(\mathrm{t}-\mathrm{km})$ for each mode of transport. For example in Europe, last decades' changes in the 'political environment' with the completion of the internal market reduced the existing barriers in national borders and resulted in increased freight transport, as companies exploited the competitive advantage of different regions

The changed 'socio-economic environment', e.g. the rising personal income in new Member States, created a greater demand for travel and private cars.

Currently transport demand is highly coupled with economic growth, and most authors agree that an efficient transport system is a prerequisite for economic development

. The challenge for policy-makers is to decouple transport demand from economic growth, i.e. to achieve high levels of economic development without increasing transport demand

The relation between transport and spatial development is well documented in the scientific literature . In summary, it is the spatial separation between economic activities (e.g. housing, employment, industry, and recreation) which brings the necessity of an efficient transport system to access 
the desired destinations (e.g. the working place) from a given origin (e.g. the residence). But the opposite also holds: the quality of the transport system plays an important role in the resulting spatial development patterns (e.g. you may choose your residence because of a good public transport provision). Therefore, combined land use and transport strategies are called for in more sustainable spatial development patterns and transport systems.

We refer here to energy availability not as the existence of primary energy resources, but as the possibilities for use in different segments of the transport sector.

Once the transport activity is fixed, it is possible to determine energy efficiency - defined as the unit consumption per unit of activity - which determines the final energy use (or energy consumption) of the transport sector.

Finally, the implementation of alternative fuels for transport is strongly related to the technological environment. Improvements in ordinary combustion engines (petrol and diesel) are being constantly introduced in new models and enhanced versions of current models. These developments had a significant influence on energy use during the last years.

Policies aimed at overcoming barriers to the implementation can be directed towards the different drivers affecting the energy use in transport. Here, we focus on policy measures to overcome barriers to the implementation of alternative fuels for road transport, given a fixed transport activity. This means that measures targeted to affect the transport activity are not further discussed.

\section{Leading developments in the use of alternative fuels for transport}

\subsection{Natural gas and $L P G$}

\subsubsection{Current status}

3.1.1.1. Natural gas. Natural gas basically consists of methane, and it therefore provides a genuine energy alternative. Natural gas can be used in engines in a liquefied form or as a compressed gas. Gas has a calorific value similar to that of diesel but due to its lower energy density it needs to be stored in pressured tanks. In order to give the vehicles a running autonomy similar to that of conventional vehicles the storage capacity must be enlarged. The gas tanks are also heavier. The body of the vehicle has to be reinforced since the tanks are usually located on the roof.

3.1.1.2. Liquified petroleum gas ( $L P G)$. LPG engines have developed alongside petrol engines on which they are based. In future years there will be a technological potential for developing new LPG injection equipment which will make the use of LPG more attractive.

\subsubsection{Market position and future potential}

3.1.2.1. Natural gas. Widespread use of natural gas as a transport fuel will require easy access to the fuel from a large number of suitable filling stations of a similar nature to the current network that would allow rapid refuelling. Currently, certified gas compression units, storage and filling systems are available to meet the necessary criteria for safe and emission-free vehicle refuelling. Suitable gas storage facilities are also available.

A range of existing conventional engines can be converted to run on natural gas. Compared with conventional vehicles, vehicles running on natural gas are characterised by the engine settings and the presence of larger volume storage tanks. Engines designed specifically for natural gas are available as prototypes. Programmes to demonstrate the reliability of these systems are currently in progress. Until this process is complete and the demand for dedicated natural gas vehicles increases, the costs of such vehicles will remain high.

There are two important market strategies for the use of natural gas, based on two refuelling stations options. The first consists of vehicle fleets with either a central base containing its own gas filling station or with negotiated access to a local commercially run gas filling station such as transport companies, postal services, urban goods distribution firms, taxis and communal business services, etc. The second consists of conventional fuel supply stations open to the public, which add gas to their supply.

3.1.2.2. Liquefied petroleum gas ( $L P G$ ). The potential for LPG use is limited by the availability of LPG in refineries (only $5 \%$ of crude oil input). Pilot demonstration projects are being implemented in several cities throughout Europe. Leading LPG engine companies are continuously carrying out R\&D activities concerning LPG engines.

\subsubsection{Barriers to implementation}

3.1.3.1. Natural gas. Financial barriers are a problem to deployment, especially in those countries at the very start in terms of infrastructure development. The capital cost of the gas powered vehicles tends to be higher than the alternatives, and prospective users of gas powered vehicles will only use such vehicles if the overall lifetime cost is less than the alternatives. This additional cost of the vehicle compared to a conventional would be eliminated if vehicles were mass-produced. However, in the current market, the development of a gas powered engine from a new fundamental concept is risky, as there is no guarantee for sufficient demand at the end of the development phase.

Likewise, the cost of implementing a widespread infrastructure of filling stations would be significant, and would need to be reflected in the price of the gas supplied. Companies are reluctant to invest on a large scale unless they are forced to, either by government legislation or by consumer pressures. Depending on different countries, this means: subsidies for domestic programmes, gas utilities being responsible for refuelling stations and providing competitive gas prices, vehicle makers providing facilities for purchasing gas vehicles.

The lack of specific legislation and safety certification provides nowadays a major barrier to the introduction of gas and 
LPG as commonly used automotive fuels. There is no legislation to regulate the use of natural gas in vehicles. In some countries there is still no commercial price for the use of gas as a transport fuel. Depending on the degree of introduction of gas as a transport fuel, each country has prepared guides and standards for use. The lack of common standards for LPG is an important inter-operability barrier, as vehicles would need to be readjusted for each different formulation of the fuel. Also, the prospect of large fluctuations in the cost of gas as a result of changing government policy or restrictions of future supply is seen as a potential disincentive by users.

Another feature of the market, which has a considerable effect on the implementation of gas as a transport fuel, is the fact that gas companies throughout Europe are not unanimous over how gas supply should be organised in terms of supplying it in compressed or uncompressed form.

The tax applicable to gas used as a fuel in transport is a decisive factor in deciding on the financial viability of this technology. Incentives of a fiscal nature should be based on the environmental improvement brought about by gas compared with the use of other fuels. The European Commission has proposed that the tax applicable to alternative energies should not exceed $10 \%$ of the amount of the tax applicable to fossil fuels. Given the loss of income that this would involve, governments have treated this proposal with caution.

3.1.3.2. $L P G$. In many European countries, there is a lack of technical information on LPG. The LPG wholesalers do not dare to have a strong marketing policy: they fear that this will attract government attention on this marginal fuel and that an LPG fuel tax will then materialise. The present infrastructure is also too old to support a sudden strong increase in demand. Therefore, a first step would be to have a government declaration certifying the prices of LPG and of the tax on LPG cars as fixed for the next years. This would give security to LPG wholesalers to start investing when the market begins to expand.

Since LPG is heavier than air, its use is subjected to certain restrictions in various countries. Workshops must be adapted for these vehicles and equipped with a fireproof electrical system, drainage $\mathbf{U}$-traps and special gas detectors and ventilation systems, all adapted to the number of vehicles used by the workshop. The right safety installations should be made compulsory in vehicles and refilling stations. The indoor parking should be adapted with specific ventilation.

Financial barriers are quite similar to those for the deployment of natural gas engines. The LPG car is still a gasoline car retrofitted for LPG. This creates a supplementary cost. However, this should not be a fundamental barrier considering the lifetime of the car and the fact that the LPG system can be taken from one car to the next one. Due to the extra cost of LPG equipment there is a need for an adequate financial regime for road taxation and for excise duty. Otherwise the turning point for the decision to use LPG will be too high. The supplementary tax for LPG cars compensates the advantage coming from the price of LPG itself for cars running less than about $15,000 \mathrm{~km} / \mathrm{year}$, when compared to a gasoline car.

The supply and distribution systems that are required for this alternative fuel could provide a significant barrier to its deployment. However, this barrier is tempered by the fact that the existing players in the market - notably the major oil companies - would also be significant players in the LPG market (as it has similar origins to more traditional fuels). An LPG station is hardly different from a petrol station. The actual distribution network could not cope with a mass increase of LPG vehicles. The rise of the market must be progressive in order to avoid bottlenecks, but strong enough to give the signal of needed investment to distribution companies.

It is unlikely that gas powered vehicles will take a significant proportion of the private vehicle market, due to the low number of public gas filling stations. However, the market for fleet vehicles, especially those based in urban areas with a regular base is likely to be a suitable target, since vehicle autonomy is limited. The vehicles that are most likely to be converted to gas power (buses and urban delivery vehicles) tend to have a relatively long service life. Therefore longterm uncertainty over gas prices and supply is likely to discourage the use of the technology. Additionally, the long vehicle life means that even if all vehicles due for replacement were replaced with gas powered vehicles, it would take a significant time before the fleet became $100 \%$ gas powered.

It is unlikely that LPG vehicles will take a significant proportion of the private vehicle market, due to both the low number of public gas filling stations and the overall limitation on LPG availability in the longer term. However, the market for fleet vehicles, especially those based in urban areas with a regular base, is likely to be a suitable target.

The fact that a car buyer must first choose between gasoline and diesel and then decide to install LPG (and pay a supplement for installation and for tax) is a clear barrier for private vehicles.

\subsection{Hydrogen}

\subsubsection{Current status}

Hydrogen is an energy carrier that needs to be derived from other fuel sources. To reduce dependence on 'foreign' fuel sources, countries search economical and efficient ways to derive hydrogen from their domestic new clean resources

Hydrogen can be produced from a variety of sources, such as biomass, natural gas, water, waste, solar photovoltaic, etc. 'Green' resources can be used to produce electricity from which hydrogen can be obtained through the electrolysis process. In transport, this process occurs in fuel cell engines. Costs are declining, even more with initiatives such as the integration of hydrogen systems for stationary power supply

Vehicle fuelling goes very well together with the management of surplus electricity production from fluctuating renewable resources such as wind power and combined heat and power productions 
Although the fuel cell technique has been known for more than 150 years now, the application to transport is still in a developing stage. Fuel cells are usually classified by their electrolyte. The main types and their potential applications are shown in Table 1.

Of all the fuel cell types it is Polymer Electrolyte Membrane Fuel Cell technique which has the biggest potential for cost reduction. So far test applications in cars proved good acceleration performance up to $90 \mathrm{~km} / \mathrm{h}$ and a maximum speed of $110 \mathrm{~km} / \mathrm{h}$. The range is $250 \mathrm{~km}$. As a long-term option, possibilities for cost reduction are considered in the reduction of catalysts load, reduction of CO sensitivity, simpler systems, which do not require pressurised operation. System development also has to consider environmental issues, such as performance during vibration, or operation and parking at outdoor temperatures between $-30^{\circ} \mathrm{C}$ and $+40^{\circ} \mathrm{C}$.

Another big research field is the development of direct Methanol Fuel Cells. This concept uses methanol as a fuel and does not need a pre-reformer. The stacks can be cheaply mass-produced and the use of methanol assures simple storage and distribution of the fuel. Major technical problems still exist. The necessary research and development will postpone a possible introduction for a longer period than for the other fuel cell types.

\subsubsection{Market position and future potential}

The use of hydrogen is a typical example of 'Social Constructionism', that is a socio-cultural revolution taking place without a strong political agenda [25]. The hydrogen economy is a movement supported by science and technology, and with strong public awareness, but not affecting the political preferences [13].

Short to medium term development of any hydrogen-based transportation will likely depend on natural gas reformation (from natural gas), which is seen as the cheapest and quickest route to hydrogen, although this does not solve the fundamental problem of the heavy reliance on fossil fuels. Also, the environmental benefits of fuel cell vehicles using hydrogen from gas are not promising. Estimates by the Joint Research Centre (2004) state that the 'well-to-wheel' carbon emissions of a fuel cell vehicle using locally reformed hydrogen in 2010 might be approximately $80-85 \mathrm{~g} / \mathrm{km}$. In contrast, the figure for a diesel hybrid will be approximately $100 \mathrm{~g} / \mathrm{km}$, which in turn represents a much more promising technological option, right from today.

Table 1

Main types of fuel cells and their applications

\begin{tabular}{ll}
\hline Fuel cell & Applications \\
\hline Solid oxide fuel cell & $\begin{array}{l}\text { Combined heat and power, } \\
\text { power generation } \\
\text { Transport, combined heat and } \\
\text { Polymer electrolyte membrane fuel } \\
\text { cell or solid polymer fuel cell }\end{array}$ \\
Alkaline fuel cell & $\begin{array}{l}\text { power, distributed power generation } \\
\text { Molten carbonate fuel cell }\end{array}$ \\
Phosphoric acid fuel cell & $\begin{array}{l}\text { Power generation, combined } \\
\text { heat and power } \\
\text { Combined heat and power, } \\
\text { power generation }\end{array}$ \\
\hline
\end{tabular}

The transition to mass market hydrogen vehicles will only be possible with a fully developed hydrogen infrastructure. This is a commonly acknowledged obstacle and therefore hydrogen taken from natural gas seems likely to provide a step on the route to an acceptable transition to hydrogen vehicles. But the practical feasibility of this option will also depend on factors other than environmental ones. Indeed, since greenhouse gas emissions of fuel cell vehicles using hydrogen from gas are broadly similar to those of diesel hybrids, the "cost" element will play a crucial role against fuel cells and strongly in favour of high-tech hybrids, at a fraction of the cost of fuel cell already today.

\subsubsection{Barriers to implementation}

There are five main issues that are critical for the introduction of hydrogen in transport

(1) The cost of fuel cell vehicles and the cost of hydrogen as a fuel are expected to continue to fall in the future as a result of the constant improvement of technologies. A crucial condition for the reduction of costs is the realization of economies of scale in both vehicle and fuel productions. The relative cost of hydrogen compared to conventional or other fuels is the main factor from the economic point of view. The boundary conditions for which hydrogen would have an advantage correspond to the case of high oil prices combined with either low natural gas prices or low electricity prices.

(2) The performance of fuel cell or hydrogen-based vehicles can potentially match with that of conventional technologies. Fuel cells even offer some advantages in auxiliary power units and some niche markets. But - everything else being equal - hydrogen-based technologies do not still offer enough advantages to shift user choices. It is obvious that in order to be competitive, they have to provide comparable performance at comparable cost, with accessible and reliable infrastructure. Otherwise, only a strong shift in user choices towards clean technologies would justify the substitution of the proven conventional technologies.

(3) Distribution and storage raise important challenges. The development of a wide network of refuelling stations is a major prerequisite, but would need a critical mass of demand before it takes off. In this context, it is indispensable that the cost of hydrogen distribution is kept low and that its introduction is massive, so that the investment costs are justified. Economically, this challenge is not as big as it might appear. In the EU, approximately 100,000 refuelling stations supply fuels to road transport. About $20 \%$ of these should be equipped with hydrogen dispensers before fuel cell vehicles are brought to the mass market. Assuming investment costs of 1.3 million Euros per station a basic refuelling infrastructure sums up to 26 billion Euros.

(4) Significant environmental benefits may occur, depending on the primary energy used for hydrogen production. Electrolysis-based solutions would only be beneficial for 
the environment as long as the electricity used for the electrolysis is produced from carbon-free fuels. Solutions based on reformation of fossil fuels would be neutral from the environmental point of view. The introduction of hydrogen in transport would therefore be feasible only in the case of low-cost renewables in electricity generation or in the case of high-performance fuel cells with low prices of natural gas or biofuels. Only stringent environmental legislation world-wide would increase the options for fuel cells, local restrictions will not open the market.

(5) The commitment of the industry could be influenced by policy. The key industrial stakeholders (car manufacturers, refineries and fuel providers, infrastructure providers, and fleet managers) will invest in a new technology only if the future market prospects are clear. The role of policymakers should therefore be that of decreasing uncertainty through suitable and timely policy measures, legislation and standards. Legislation could also influence user choices, by promoting the use of hydrogen, penalising $\mathrm{CO}_{2}$ emissions, or by limiting the use of conventional technologies in certain areas.

The year 2020 seems to be too early for a wide scale introduction of hydrogen or fuel cells; it is questionable whether even year 2030 is a feasible time horizon. But it is also clear that even if the goal is the shift to hydrogen after year 2030 , the preparation needs to start already.

\subsection{Biofuels}

\subsubsection{Current status}

Biofuels are liquid fuels produced from biomass feedstock via a number of chemical processes. The two biofuels that have advanced the most are biodiesel (produced from vegetable oil) and bioethanol and its derivative ethyl tertiary butyl ether (ETBE) (produced from plant sugars). Other liquid biofuels have been researched but have not gained the commercial potential and market share.

A Life Cycle Analysis (LCA) of biodiesel compared to petroleum diesel shows that the advantages of biodiesel concentrate on the energy balance and greenhouse gas control. However, the weaknesses or areas of concern are the higher $\mathrm{NO}_{x}$ and Total Hydrocarbon (THC) emissions, which are subject/ opportunities for further research

Biodiesel can be operated in any diesel engine with little or no modification to the engine or the fuel system. The technologies for the production of these liquid biofuels are wellunderstood chemical processes using proven techniques. Typical feedstocks for these fuels are mainstream agricultural crops. The conversion technology in itself is low risk because it is well proven. The development of the liquid biofuel industry was quite quick because of this, but major reductions in the cost of biofuel production have not occurred because of the relatively high feedstock costs.

Most countries have tailored standard practices to their own situation. This has largely depended on the different feedstocks and the final application of the biofuel (mainly transport). A well-known example is the heavy focus on biofuel production in Brazil. Research into the production processes has focused on the efficiency of the conversion, and hence reducing the costs of production. Investigations in Europe into using lignocellulosic material are underway. There are, however, some constraints to this, including the high cost of the enzymes and the strength of the agricultural sector which continues to campaign for the profitable industrial use of food crops grown on set-aside land. The main scope for innovation is the use of waste cooking oil or lignocellulosic material as cheaper feedstock. These will help to reduce the costs of fuel production quite considerably and help to make it more competitive with fossil fuels.

\subsubsection{Market position and future potential}

The main factors, which have been instrumental in the production of biofuels in Europe, are very similar for the rest of the world: the need to develop an indigenous transport fuel supply because of the dependence on imported fossil fuels, and expensive storage of over produced agricultural produce. The commercial availability of the fuel will depend on: the scale of industrialisation and access to a suitable conversion technology, a suitable infrastructure to get the product to the consumer and public support for the use of liquid biofuels, particularly when food crops have been used in their production.

Europe has taken the lead position in the production of biodiesel across the world, with a current production of over 500,000 tons, and an installed capacity of 1 million tons in over 20 production sites, capturing $1 \%$ of the diesel market. The Directive on the promotion of Biofuels Directive 2003/ 30 [28] sets an indicative target of replacing $5.75 \%$ of petrol and diesel consumptions by biofuels for transport purposes. There is a very attractive technology potential for both biodiesel and bioethanol of $12 \%$ of market share by the year 2020 , which equates to 45 million tons.

There are a number of key interacting factors which have led to the commercial availability of liquid biofuels in some European countries and not in others. The reasons are usually political, but the source of the 'political will' may vary, for example, the widespread introduction of set-aside agricultural land. Production of non-food crops, oilseed rape or sunflowers for methyl ester production would appear to be an ideal alternative. Coupled with the actual or perceived environmental benefits of biofuels, there is a very strong agricultural lobby for their development and use. In addition, some governments have chosen to implement a certain level of tax relief for pilot biofuel production plants . Clearly, where countries have implemented this scheme, there is considerably greater incentive to produce the biofuel; without this tax relief, it is very difficult to compete.

The more sophisticated conversion technologies (enzymatically catalysed options) are likely to benefit from further $\mathrm{R} \& \mathrm{D}$ to reduce costs.

\subsubsection{Barriers to implementation}

The availability of information to potential investors is mixed across Europe. This is largely due to the conflicts surrounding the environmental benefits of the fuel. Farmer co-operatives 
and trade associations have tried to promote the exchange of information. More co-ordinated information availability is likely to facilitate future investments in biofuel technologies.

The main risk for the deployment of liquid biofuel technology across Europe is the uncertainty surrounding feedstock availability. The set-aside scheme was hailed as a suitable mechanism to promote non-food crop production. If farmers were restricted from growing food crops, then the land could be suitably used for other applications. However, the great success of the set-aside scheme in reducing cereal crop surpluses has lead to decreasing percentages of land to take out of food production, and has destabilised the non-food crop industry, rather than enhancing it. The variable set-aside rate has lead to uncertainty in the agricultural sector. Other mainstream food crops in many cases provide better returns than oilseed rape for industrial purposes on non-set-aside land. This competition for land use will continue to be a problem, and as such, farmers will be reluctant to enter into long-term supply contracts for crops whose return may fall in comparison to other crops.

The main restriction across the EU on the further development of the biodiesel industry is the 1993 Blair House agreement which is part of GATT. This agreement imposes a limit on the amount of rape meal that could be produced as a byproduct from industrial oilseed crops grown on set-aside land across the EU to the equivalent of 1 million tons of soy meal per year. This equates to approximately 900,000 ha of oilseed production across the EU.

Another key legislative barrier to fuel use is the lack of $a$ common European standard. These standards are a prerequisite for the approval of liquid biofuels by engine manufacturers and the public, whose confidence in the fuel will be undermined without a stamp of quality.

The price distortion for liquid biofuels normally works in its favour, i.e. the tax relief which enables it to compete with fossil fuels. However, the complex nature of the calculation for crude oil inevitably means that the final price is distorted. There are price distortions in the feedstock market as well as in the marketplace for fuel. This is particularly the case for oilseed rape which has a noticeable price difference depending upon whether it is sold for the food market or for the non-food market.

\section{Policy options to overcome barriers to implementation}

Governments can play an important role in stimulating innovation and introductions of new technologies in the transport energy sector . In Europe, significant public sector involvement is needed to provide mechanisms for coordinating activities efficiently, and to stimulate cross-business and crossborder co-operation . In the Green Paper on Energy Efficiency , National Annual Energy Efficiency Action Plans are proposed, to identify measures to be taken at national, regional and local levels. This requires a regulatory and economic framework that provides long-term price signals (i.e. incorporating environmental and other considerations as far as is possible) to both energy suppliers and end-users, so that they can plan their actions effectively
Policies affecting energy use in transport are further classified as the following: market incentives, policies targeting technology and vehicle efficiency, and overall system improvement. In general, a combination of policies is required

, and a number of supporting measures, such as public education, increase the effectiveness of many political measures

\subsection{Market incentives}

\subsubsection{Fuel pricing measures}

Fuel pricing measures consist of fiscal incentives to encourage the use of certain energy sources and their end-use applications. Some policy documents consider taxation as the most flexible and effective instrument in the increasingly open market for encouraging operators to change their behaviour

Fuel tax seems to be the only pricing instrument related to vehicle usage, which is applied throughout the EU. Road pricing schemes are also related to vehicle usage, but until now their application is limited to motorways in some Member States and to very specific road parts in some urban areas. Therefore fuel taxes are still seen as the most efficient instrument currently available, not only for internalising social costs linked to the use of vehicles, such as infrastructure costs, accident costs and air pollution costs, but also to promote cleaner fuels and alternative energy sources in transportation. Notwithstanding, some studies have shown that despite the fact that fuel demand is quite elastic, making fuel taxation the best way to reduce fuel use, it seems almost impossible to do so, particularly in those countries with low prices and high demand . There are indeed great difficulties in raising fuel taxes. One of the reasons for the difficulties is that political pressure influences the decisions regarding taxation of fuel consumption. Not only low taxes and thus low prices encourage high consumption, but high levels of consumption also lead to considerable pressure against raising the taxes.

Given the price inelasticity of transport energy demand, the level of taxation has to be high and persistent to ensure a coherent price signal. Fiscal measures are preferably implemented through simple, administratively inexpensive, possibly progressive, methods, accessible to all parties concerned. The level of effectiveness of fuel pricing measures also depends on many country-specific characteristics. In countries with low taxation high fuel taxes may support technical progress

In the EU Member States, the tax on energy products varies per product and per Member State, as well as the share of total tax revenues from transport and energy sectors. Currently, coal and natural gas are generally the least taxed and oil the most heavily taxed energy products. Coal benefits from State aid in the coal-producing countries. Although it is perfectly logical to relieve coal of any tax burden while it is receiving substantial State aid, the result is to promote imported coal to the detriment of alternative but more heavily taxed energy sources such as natural gas and oil. Although natural gas is generally more heavily taxed the rates are in general still low. Renewable energy sources currently benefit from tax 
exemptions or reductions, but not equally across Member States. Some energy production from renewable sources is already exempt from all taxes, such as solar heat and power for domestic use.

The causes of the existing different levels of taxation between Member States are very complex. They point to tax approaches accentuating either a main objective of generating budget revenue, economic policies to develop sectoral competitive advantages or even environmental, social and regional considerations. Besides the product/end-use differentiation, Member States use widely diverging methods for the definition of the tax rate and for allowing exemptions and tax refunds. Some Member States also provide subsidies, such as for coal production. Tax exemptions and refund arrangements complicate the situation further.

There is nonetheless one constant: most of the revenue drawn from energy taxation is from mineral oils. A general observation across Member States is that domestic and transport use of energy is more heavily taxed than industrial use. Another general observation is that mineral oils for automotive use are more heavily taxed than for other use.

This lack of harmonisation in the European Union sends an inconsistent message conflicting with the security of supply objectives, and can also lead to excess tax competition. A Member State wishing to introduce a tax on an energy product could be prevented from doing so if this product is not taxed in a comparable way in a neighbouring country, for fear of delocalising some of its economic activities. Member States thus lose some of their decision-making independence on tax matters. Generally, the lack of Community energy taxation structures affects the unity of the internal market and the liberalisation of gas and electricity markets could even come under threat. It also reduces Member States' scope for carrying out the necessary tax reforms. Similarly, it is incompatible with certain policies with which it interacts, including with security of supply.

A Community energy tax framework can be a very efficient tool [1]. Community regulations have numerous advantages over laws adopted in a national context, particularly in terms of the functioning of the internal market and harmonisation of competition within the EU. The Community is the optimum level at which to set the main guidelines for energy, transport and environmental tax policy. The Community is also the right framework, in that problems of actually implementing certain aspects of energy or environmental protection policy are linked to State aid rules. Upward harmonisation of tax rates between Member States is therefore unavoidable. The fiscal instrument should aim to eliminate national distortions and distortions between energy producers, encourage more energy saving and lead to the internalisation of damage caused to the environment.

EU fuel taxation is seen today as the best available fiscal tool to control the amount of diesel and petrol used, and hence energy consumption and emissions from the transportation sector. The excise duties applicable can be arranged to be close to the average value of the external costs, increasing the price by the required amount to correct for level of use.
Fuel taxes may be differentiated endorsing targets such as promotion of 'cleaner' fuels (unleaded petrol) or low-sulphur diesel, biofuels, natural gas (at present). The aim is to comply with the stringent $\mathrm{EU}$ standards, helping to reduce $\mathrm{NO}_{x}$, PM10, and $\mathrm{CO}_{2}$, although sometimes at the expense of extra production costs and refinery emissions (for oil based improved/de-sulphurised fuels). Fuel tax is indeed the only pricing instrument used throughout the $\mathrm{EU}$ that is related to vehicle usage. Road pricing schemes are also related to vehicle usage, but to date their application is limited to motorways in some Member States and to very specific road cordons in some urban areas. Therefore fuel taxes are seen to be the most efficient instrument currently available, not only for internalising social costs linked to the use of vehicles, such as infrastructure costs, accident costs and air pollution costs, but also to promote cleaner fuels and alternative energy sources in transportation.

Since the early 1990 s the use of taxes to achieve environmental goals by means of 'green taxes', $\mathrm{CO}_{2}$ tax, vehicle taxes, tax incentives, has been at the centre of discussions. In May 2001, the European Commission presented a comprehensive strategy for the EU's future taxation policy and a common framework including differentiated rates according to environmental objectives was finally set up by the EC in the Energy Products Directive 2003/96/EC that came into force at the beginning of 2004, restructuring the Community framework for the taxation of energy products and electricity.

This EC Directive that came into force on 1st January 2004 widened the coverage of the Community framework, previously limited to mineral oils, to all energy products including coal, natural gas and electricity and increases the relevant Community minimum rates of taxation. The objective was to reduce distortions of competition acknowledged between Member States as a result of divergent rates of tax, i.e. reduce distortions of competition between mineral oils and the other energy products not previously subjected to Community tax. The Directive defines exemption regimes, according to a number of principles that include LPG, natural gas and methane in specific applications such as public transportation, waste-collection, drain suction and street-cleaning vehicles, and reduction in the rate of excise duty on heavy fuel oil to encourage the use of more environmentally friendly fuels.

A very particular case for biofuels in Europe has further determined the adoption of a formal position of EC Policy by means of the Directive 2003/30/EC, envisaging the promotion of the use of biofuels for transport purposes, while meeting goals related to the Common Agricultural Policy, too. But the question of biofuels in transportation tends to divide specialists. Some believe that biofuels should be promoted, as the $\mathrm{EC}$ did recently. But for other international institutions, like the International Energy Agency (IEA), one should be cautious regarding biofuels, raising questions about what can actually be done and what is the actual potential for a substitution to the extent required in the 2020 targets. Some argue that this will lead to an industrialised, polluting agriculture and insist on the importance of limiting promotion of biofuels to products derived from agricultural practices which are less 
environmentally harmful and which require less chemical inputs than today's agriculture. Doubts are also expressed about the likely costs of biofuels. Some say that they would be more cost-effectively used for heating than for transport purposes. Others argue that there is a broader range of options available to reduce fuel use in transportation and improve efficiency than those considered in the Green Paper, such as pricing of vehicles and transportation, and tax and technology support to increase energy efficiency. It extols that Member States must ensure that the minimum share of biofuels sold on their markets is at least $5.75 \%$ by December 2010. Any Member State setting lower objectives will have to justify this on the basis of objective criteria. In complement to this specific Directive the previously mentioned Directive 2003/96/EC has incorporated in its Article 16 a provision for Member States to opt for applying a reduced rate of excise duty to pure or blended biofuels, when used either as heating or motor fuel. This directive, unique by its clear support to a specific fuel, reflects therefore a strong bet from the EU policy in biofuels to meet decreased energy reliance on external sources and environmental targets. However, it should also be taken into account that current policies related to biofuels in many countries, and particularly in the EU, appear to be driven largely by agricultural concerns, as agricultural policy serves multiple EU objectives. It is therefore questionable whether a strong biofuel policy in Europe will effectively be able to serve fully the EC transport energy-related targets.

\subsubsection{Tax incentives and credits for efficient technologies}

Giving tax incentives to both companies and consumers to reach a sufficient production volume for economies of scale to make the cost of a new product competitive is suggested as a powerful instrument at the EU level. One example at the EU level is the use of public procurement to help kick-start new efficient technologies

The EC legislation is aimed at contributing towards the creation of a market for clean vehicles. The proposal for a $\mathrm{Di}$ rective COM (2005) 634 requires public bodies to allocate a minimum quota of $25 \%$ of their annual procurement of heavy-duty vehicles requirements to "enhanced environmentally friendly vehicles' (EEV) (as defined in Directive 2005/ $55 / \mathrm{EC}$ ). This new European rule will make it possible to give manufacturers the assurances they need in order to develop these vehicles for a larger market.

Directive 2003/96/EC of 27 October 2003 restructuring the Community framework for the taxation of energy products and electricity already allows, under certain conditions, differentiated excise duty rates for alternative fuels such as biofuels, natural gas, and LPG. Also, the Commission presented a proposal for a Directive (COM (2005) 261 of 5th July 2005) requiring taxation of passenger cars to be based at least partially on $\mathrm{CO}_{2}$ emissions in order to encourage the purchasing of cleaner and more energy-efficient vehicles. It also includes an invitation to Member States to apply coordinated fiscal incentives for passenger cars fulfilling the so-called "Euro" standards on vehicle emissions.
Tax incentives are considered by international energy organizations, such as the IEA, as policy measures capable to help manufacturers justify mass marketing and offset the relatively high first cost premium for these new technologies, thereby helping to build sales and market share. In this context, policy options, such as performance-based tax incentives and credits for advanced technologies, may help to jumpstart the introduction and purchase of advanced vehicles. Other possibilities include supporting technology purchase consortia that would form groups of buyers large enough to interest manufacturers in making the investment to produce the technology. Once the new technologies become widely available and produced on a significant scale, costs should decline and these incentives could be phased out. However, there is a risk of a free-rider effect if these direct subsidies are used for investments that would have been made anyway

There is a wide variety of possible instruments to encourage the development of new efficient technologies. Various "incremental" technologies can be applied to conventional vehicles at very low or even negative cost, when taking into account fuel savings. Tax incentives for hybrid vehicles save energy directly and help to establish these innovative products in the marketplace. Another example of tax incentives used in several countries is the restriction of used car imports by setting a maximum allowable age, usually two to four years, mainly for safety reasons and emission performance. Tax incentives for cars with better emission or efficiency performance could speed the stock-turnover process, while high car purchase taxes would slow down the stock-turnover rate.

For freight transport, targeted incentives might also increase the adoption of advanced technologies. These could be tax reductions for heavy-duty trucks that have certain levels of fuel consumption per unit size or weight, or that possess specific technologies meeting strict performance criteria. These incentives could be either tax credits or subsidies that would make the vehicles competitive with conventional ones. These fees or sales taxes on new heavy-duty vehicles could be partly based on unloaded vehicle weight, engine efficiency, or tested fuel consumption. Such incentives may overcome concerns by truck owners about the reliability of new technologies that are not completely proven.

\subsubsection{Vehicle taxation}

Vehicle taxation in the European context has been an increasingly discussed subject in the last few years. Despite all the convergence treaties, this issue remains an exception. There is currently little Community legislation, or harmonisation of national fiscal provisions, applied by the Member States in the area of passenger car taxation. It is for each Member State to lay down national provisions for the taxation of cars. Hence Member States' taxes on passenger cars are much diversified in terms both of their structure and levels. They include tax payable at the time of acquisition of the car (registration tax), periodic tax payable in connection with the ownership of the passenger car (annual road tax), taxes on fuel, and other taxes such as VAT, insurance taxes, registration fees and road tolls. 
In countries where energy and environmental concerns are at the core of the taxation rationale, both acquisition and ownership taxes tend to be relatively high. At the other end of the spectrum are countries like Portugal or Greece, where taxation levels tend to be strongly tied to tax revenue on acquisition. As motorization growth rates in these countries are flattening, the trend will be to transfer vehicle taxation to ownership, bringing greater stability in terms of tax revenue as well as flexibility to incorporate energy-related policy criteria, such as energy consumption, type of fuel, age, etc. As a tool to condition and drive technological choices, combinations of acquisition and ownership taxes are likely to have the greatest effect. Denmark is a good example of this policy.

In 2005, the European Commission set up a strategy on the taxation of passenger cars in the European Union . Apart from concerns on removing tax obstacles and distortions to free movement of passenger cars within the Internal Market, other targets are the relationship between taxation principles and energy/emission related EU policy objectives. Registration taxes are identified as the biggest problem and therefore the Commission recommends their gradual reduction and even abolition, to be replaced by annual road taxes and fuel taxes (so that the tax burden would remain the same but related to the use of a car rather than its acquisition). For the existing vehicle taxes, the Commission recommends that the taxation of new passenger cars be more directly related to their $\mathrm{CO}_{2}$ emissions, urging Member States to take these recommendations into account when evaluating and revising their national vehicle taxation systems.

The Commission now recommends that both acquisition or registration tax and annual ownership tax should be based primarily on emission factors, recommending the gradual phasing out of registration taxes and the introduction of a new tax structure linked to $\mathrm{CO}_{2}$ emissions. It also recommends that taxation of the use of company cars should also include a clear and strong incentive to use more $\mathrm{CO}_{2}$ efficient cars.

From the options proposed for the resolution of the generally identified problems in relation to vehicle taxation, the option that received wider consensus from motor industry and consumer associations does confirm suggestions to phase out registration tax gradually while introducing a new tax structure linked to $\mathrm{CO}_{2}$ emissions.

\subsection{Technology and vehicle efficiency}

A number of alternatives for combustion engines are already on the market, such as natural gas vehicles, hybrids and electric vehicles. The implementation of alternative fuels strongly depends on the (further) implementation of these technologies. Policy measures to overcome barriers to the implementation of alternatives to fossil fuels therefore include measures to stimulate the use of more new vehicle technologies.

\subsubsection{Regulatory standards}

Regulatory environmental standards set either technology standards or performance standards, enforceable through fines and other penalties. There is no general agreement on terms by which regulatory standards are classified. They may apply to a product, a line of products, or the provision of a service.

Standards may be set up on the basis of energy efficiency parameters, technology based, or on the basis of emissions. The definition of the standards should tackle the existing trade-offs among environmental issues, e.g. fuel standards based on emission rates of individual substances may have positive implications on air pollution while producing a negative influence on climate change issues

Although all regulatory standards have consequences on economic decision-making, they differ from market-based instruments, which operate by directly changing relative prices rather than by specifying technology or performance outcomes. The existence of national energy conservation laws is a key factor for the establishment of legal framework in which these standards should be inserted

EU legislation has regulated vehicle emissions through the so-called "Euro" standards, with limit values becoming tighter over the years. The latest standards implemented are Euro 4 standards for passenger cars and light-duty vehicles, as from January 2005. A proposal for Euro 5 for passenger cars and light-duty vehicles will follow in 2006. Relating to heavy-duty vehicles, Euro 4 standards are in force from October 2005 and the Euro 5 standards will enter into force in 2008 .

One of the first examples of a successful implementation of environmental regulations is the case of California [37]. Similar regulations are now being adopted in other countries in Europe and Asia. The use of energy efficiency standards is widespread - they are implemented in over 50 countries and its number is still growing. However, their effectiveness is uneven: energy efficiency standards are most effective in countries with high and growing consumption and in countries in which consumers' energy awareness is low because of historically low energy prices [36].

Regulatory standards can be effective policies to address market failures and barriers, as they reduce the need for information, high transaction costs, and dissemination to, consultations with, and training of millions of households, car drivers, and small and medium size companies [32]. They are also widely used to require actors to account for environmental externalities and, if continually modified to account for technical progress, they can provide dynamic innovation incentives.

Developing minimum standards (i.e. maximum levels of fuel consumption) aimed at improving the worst performers in each category might be politically acceptable and offer a way to begin setting standards, but may save little fuel. Another approach - followed by the Japanese Top Runner Programme - is to set fuel efficiency targets and/or goal efficiency requirements. In this Programme, the approach for light-duty vehicles identifies the most fuel efficient models in each vehicle class and requires future models to meet a level of fuel consumption close to the current (or expected future) best. Top runner improves average fuel 
efficiency both by encouraging improvements from (or elimination of) the worst vehicles, and continuous improvements from the best vehicles. A similar approach could be established for heavy-duty trucks.

The development of an effective regulatory standard requires national and, potentially, international, leadership to balance the interests of manufacturers, consumers, environmental non-government organizations (NGOs), and other interest groups, while creating sufficient societal support and incentives for successful implementation. While decisions to introduce regulatory standards are commonly made by legislatures, the development and implementation of standards over time are often left to a less transparent public administration.

Regulatory standards may also be used to correct barriers that arise from information failures and can yield net benefits to society if the costs associated with the regulation are less than the losses due to informational barriers. At an international level, the International Energy Agency [34] recommends the adoption of a more aggressive role in developing support infrastructure, codes and standards that will be critical in speeding the early adoption of advanced vehicle technologies as they become ready. Here too, greater co-ordination among OECD member governments could speed progress.

\subsubsection{Voluntary agreements}

No international definition of a voluntary agreement (VA) is universally accepted. Among these, the definition given by the Intergovernmental Panel on Climate Change (IPCC) has been considered the one that best fits with the purpose of this paper. It defines a VA as "an agreement between a government authority and one or more private parties, as well as a unilateral commitment that is recognized by the public authority, to achieve environmental objectives or to improve environmental performance beyond compliance"

VAs may take a wide variety of different forms. Sometimes they involve agreements between the government and a set of firms, but in other cases industry associations represent member firms. Sometimes the agreement only relates to general issues, such as R\&D activities, reporting on emissions, or energy efficiency, but in other cases specific quantified targets, such as emissions targets, are agreed upon. A few VAs are legally binding once signed, but most are not.

The most significant example in the EU is the voluntary agreement to reduce $\mathrm{CO}_{2}$ emissions (and increase fuel efficiency) of new vehicles by the European Car Manufacturers (ACEA), Korea and Japan

Although VAs are relatively new environmental policy instruments, they are gaining popularity as a tool to cope with environmental issues. The fact that in 1996 in the EU alone there existed more than $300 \mathrm{VAs}$, suggests that this type of policy measure is administratively and politically feasible, especially if it is used in a policy mix or in new policy areas. VAs are political feasible simply because most of the industries seem to prefer VAs over other tools. However, VAs may not be a satisfactory substitute for mandatory efficiency standards
Sometimes the "voluntary" aspect of a VA is questioned, as when the main motivation for industries to join the VA was to avoid the implementation of a carbon and/or energy tax and/or other mandatory policy. Proponents of voluntary approaches point to the low transaction costs, the merits of the consensus elements in the approach, and the advantages of leaving the choice of abatement measures to the participants.

To assess the effectiveness, the trade-off between how ambitious the objectives are and how well they are attained should be recognized. There is a suspicion that, as most VAs are non-binding, they may not attain ambitious goals VA objectives may be less stringent if environmental groups are left out off the negotiation process.

Since VAs are a relatively new policy instrument to cope with environmental issues, it is too early to determine their effectiveness. Besides, from a methodological perspective, it is rather complex to assess the effectiveness of VAs because it is difficult to establish a counterfactual. The OECD (1998) noted that no empirical evidence is available on the cost-effectiveness of VAs. The CEC (1996), however, argues that the flexibility of VAs provides room for industries to find the most efficient way to achieve the targets, which could be a major advantage. The EEA (1997) concluded, after analyzing six case studies of European VAs, that, while there was quantitative evidence for environmental improvement in most case studies, more sophisticated analysis would be necessary to distinguish between the effects of the VAs and those of other factors [39]. In the same study it was recognized, however, that in five of the six cases the interviewed experts felt that VAs incurred lower costs than alternative instruments.

\subsection{Overall system improvement}

\subsubsection{Informational measures}

Information gaps result in uncertainties, risks, and missed opportunities. They are usually considered as the first barrier to energy efficiency. Policy measures aimed at the development of a clearer picture of the costs, benefits and challenges involved in different technologies are considered as rapid, relatively low-cost measures

Recent EU policy documents have stressed the need to give the citizens better information. Key actions include an improved EU energy-labelling strategy, and better targeted education/awareness campaigns.

The European car labelling system is an example of a policy instrument that enables potential car buyers to make an informed choice, since it obliges Member States to ensure that information on fuel consumption and $\mathrm{CO}_{2}$ emissions of new private cars is available to consumers.

Government support (fiscal, financial and regulatory) is needed for demonstration and pilot projects, through direct or indirect actions, including fuel duty rebates and enhanced capital allowances

The HyLights initiative (http://www.hylights.org) is a recently launched co-ordination action funded by the European Commission, set up by European institutes and industry partners to accelerate the commercialisation of hydrogen and fuel 
cells in the field of transport in Europe. HyLights will assist all stakeholders in the preparation of the next important phase of the transition to hydrogen, through large-scale demonstration activities throughout the EU.

Demonstration activities are essential to achieve a sufficient visibility, to gain public acceptance and to create confidence in the transition phase of hydrogen as a fuel for vehicles

Recent initiatives in this line are the EU funded projects Clean Urban Transport for Europe (CUTE) and Ecological City TranspOrt System (ECTOS) aimed at testing the feasibility of Hydrogen Fuel Cell Powered buses in EU urban public transport systems. More information on these projects can be found on the website: http://www.fuel-cell-bus-club .com. These demonstration projects are helping the build-up of infrastructure with different pathways for supplying hydrogen, while supporting European-wide co-operation of related companies and institutions.

CIVITAS (http://www.civitas-initiative.org), a major initiative launched in October 2000, aims to support Clean Urban Transport actions across Europe. Within the CIVITAS Initiative, the EC supports and evaluates the implementation of ambitious integrated sustainable urban transport strategies that should make a real difference for the welfare of the European citizen. Within CIVITAS I (2002-2006) there are 19 cities clustered in four demonstration projects, whilst within CIVITAS II (2005-2009) 17 more cities in four demonstration projects are taking part. CIVITAS includes eight different policy measures fields. Each CIVITAS city chooses an appropriate set of measures from those building blocks and combines them to form integrated solutions for clean urban transport in cities. In addition, it puts in place the appropriate planning framework, ensures political involvement and support, and establishes the necessary partnerships to ensure delivery of the plans among which there is one called "Clean fuels and vehicles", which includes, among others biodiesel, biogas/ CNG, fuelling stations, hybrid vehicles/e-vehicles and LPG.

Awareness campaigns about climate change issues also influence the people's perception about their energy use in transport. An example of an awareness campaign funded by the European Commission is the 'Sustainable Energy Europe 2005-2008' Campaign. The goal is to raise public awareness, persuading both consumers and key decision-makers of the benefits of sustainable energy production and use. It is aimed at contributing to achieve the EU's energy policy targets within the fields of renewable energy sources, energy efficiency, clean transport and alternative fuels.

ManagEnergy (http://www.managenergy.net) is an initiative of the European Commission which aims to support the work of actors working on energy efficiency and renewable energies at the local and regional levels. The main tools are workshops and online events. Additionally, information is provided on case studies, good practice and European legislation.

This can also help Governments communicate their targets and increase the acceptability of policy measures to the public. A wider dissemination of the results of energy-efficient Community programmes is a crucial condition for ensuring that technological discoveries are more widely and rapidly used.
For freight transport, information campaigns for trucking companies about available or near-term technologies, and the potential benefits of investing in them could also be effective informational measures.

\subsubsection{Investments in $R \& D$}

The energy R\&D funding of the EU and Member States has been reduced in the period 1990-2003. This global decline was motivated by reductions in nuclear fission, fusion and fossil fuels, while funding for alternative fuels increased by $10 \%$ and more than doubled for power and storage technologies

Improvement of conventional and development of alternative vehicle technologies has been supported by Community funding through the research and technical development (RTD) Framework Programmes and the Structural Funds. The 7th RTD Framework Programme recognises that there is no single solution to our energy problems, and therefore suggests a wide portfolio of recommendations: supporting renewable energy technologies, making clean coal and carbon capture and sequestration an industrial reality, developing economically viable biofuels for transports, new energy vectors such as hydrogen and environmentally friendly energy usage (e.g. fuel cells) and other energy efficiency measures.

In this context, European technology platforms on biofuels, hydrogen and fuel cells, photovoltaics, clean coal and electricity networks are aimed at developing commonly agreed research agendas and deployment strategies. However, a substantial increase in public support in hydrogen and fuel cells is still needed for Europe to compete with the US and Japan. To be as effective, a strategic research agenda at an EU level, guiding Community and national programmes in a concerted way is needed to achieve sufficient critical mass and avoid unnecessary duplication

For this purpose, the European Commission has launched initiatives such as the European Hydrogen and Fuel Cell Technology Platform (https://www.hfpeurope.org) to become a major instrument to coordinate and structure the planning for the introduction of hydrogen energy in Europe. The main goal of the HFP is to facilitate and accelerate the development and deployment of cost-competitive, world-class European hydrogen and fuel cell based energy systems and component technologies for applications in transport, stationary and portable power. The technology platform is instrumental in structuring socio-economic and technical research on hydrogen and fuel cells at European level, as well as in stimulating increased public and private investments in research and development.

Finally, nationally funded $R \& D$ has proven its effectiveness to speed up innovation and reduce its costs, helping to bring small and medium size enterprises (SMEs) into the R\&D playing field

\section{Conclusions}

Regardless of the type of alternative fuel, there are obstacles of a structural nature to its development. Most important innovations are developments of reliable technology. One risk 
involved in the implementation of alternative fuels for road transport is the acceptance of vehicles implementing new technology. The investment risks in new technology are also high. Manufacturers are unlikely to take such risks unless the regulatory framework both enforces and supports the development of new engine technologies. The role of policy-makers should therefore be that of decreasing uncertainty through suitable and timely policy measures, legislation and standards.

The additional cost involved in applying new technologies will gradually go down as their use becomes more widespread. But it must be taken into consideration that for road transport, differential duty on different types of fuel or taxes based on the engine could have a large impact on the future implementation of alternative fuels.

\section{Acknowledgements}

The research was conducted as part of the project "Scenarios for the Transport System and Energy Supply" (STEPs), Framework Programme 6, Call 1A, Thematic Priority 1.6.2, Area 3.1.2, Task 1.10.

\section{References}

European Commission. Green paper: a European strategy for sustainable, competitive and secure energy. COM; 105 final. Brussels: Commission of the European Communities; 2006.

European Commission. Green paper on energy efficiency or doing more with less. COM; 265 final. Brussels: Commission of the European Communities; 2005.

European Commission, European Environment Agency. Energy and environment in the European Union. Tracking progress towards integration. EEA Report No. 8/2006. Copenhagen; 2006.

European Commission, European Environment Agency. Transport and Environment: Facing a Dilemma. TERM 2005: indicators tracking transport and environment in the European Union. EEA Report No. 3/2006. Copenhagen; 2006.

Stead D. Transport intensity in Europe - indicators and trends. Transport Policy 2001;8(1):29-46.

European Council, Brussels, 22 and 23 March 2005 summit conclusions. Ref. 7619/1/05.

Hackney J, de Neufville R. Life cycle model of alternative fuel vehicles: emissions, energy, and cost trade-offs. Transportation Research Part A: Policy and Practice 2001;35(3):243-66.

Delucchi MA. A multi-country analysis of lifecycle emissions from transportation fuels and motor vehicles. Report No. UCD-ITS-RR-0510. Davis: Institute of Transportation Studies, University of California; 2005.

European Commission, European Environment Agency. Air pollution and climate change policies in Europe: exploring linkages and the added value of an integrated approach. Technical Report No. 5/2004. Copenhagen.

Saleh WS, Nelson JD, Bell MGH. Determinants of energy consumption examination of alternative transport policies using the temis program. Transportation Research Part D: Transport and Environment 1998;3(2): 93-103.

Reddy S, Painuly JP. Diffusion of renewable energy technologies - barriers and stakeholders' perspectives. Renewable Energy 2004;29(9):1431-47.

Tseng P, Lee J, Friley P. A hydrogen economy: opportunities and challenges. Energy 2005;30(14):2703-20.

Clark WW, Rifkin J, O'Connor T, Swisher J, Lipman T, Rambach G. Hydrogen energy stations: along the roadside to the hydrogen economy. Utilities Policy 2005;13(1):41-50.
Saidel MA, Alves SS. Energy efficiency policies in the OECD countries. Applied Energy 2003;76(1-3):123-34.

Litman T. Efficient vehicles versus efficient transportation. Comparing transportation energy conservation strategies. Transport Policy 2005;12(2): 121-9.

Farinelli U, Johansson TB, McCormick K, Mundaca L, Oikonomou V, Ortenvik M, et al. "White and Green": comparison of market-based instruments to promote energy efficiency. Journal of Cleaner Production 2005;13(10-11):1015-26.

Rietveld P, Nijkamp P. Transport and regional development. In: Polak J, Heertje A, editors. European transport economics. Oxford: Blackwell Publishers; 1993. European Conference of Ministers of Transport (ECMT).

Button KJ. Alternative approaches toward containing transport externalities: an international approach. Transportation Research Part A: Policy and Practice 1994;28(4):289-305.

Banister D, Stead D, Steen P, Akerman J, Dreborg K, Nijkamp P, et al. Targets for sustainable mobility. In: European transport policy and sustainable mobility. London: Spon Press; 2000

Geurs KT, van Wee B. Land-use/transport interaction models as tools for sustainability impact assessment of transport investments: review and research perspectives. The European Journal of Transport and Infrastructure Research 2004:4:333-55.

Geurs KT, van Wee B. Accessibility evaluation of land-use and transport strategies: review and research directions. Journal of Transport Geography 2004;12:127-40.

Badoe D, Miller E. Transportation-land use interaction: empirical findings in North America, and their implications for modelling. Transportation Research D: Transport and Environment 2000;5(4):235-63.

Clark WW II, Rifkin J. A green hydrogen economy. Energy Policy 17: 2630-9.

Lund $\mathrm{H}$, Münster E. Management of surplus electricity-production from a fluctuating renewable-energy source. Applied Energy 2003;76:65-74. O'Garra T, Mourato S, Pearson P. Analysing awareness and acceptability of hydrogen vehicles: a London case study. International Journal of Hydrogen Energy 2005;30(6):649-59.

European Commission, Joint Research Centre. Hydrogen prefeasibility study: final report (ESTO/JRC/SETRIS). EUR 21512EN.

Sheehan J, Duffield J, Shapouri H, Graboski M, Camobrero V. An overview of biodiesel and petroleum diesel life cycles. CO: National Renewable Energy Laboratory, US Department of Energy; 1998.

2003/30/EC of the European Parliament and of the Council of 8 May 2003 on the promotion of the use of biofuels and other renewable fuels for transport. OJEU L123 of 17 May 2003.

European Commission. Communication of the European Commission of $07 / 11 / 2001$ on an action plan and two proposals for directives to foster the use of alternative fuels for transport, starting with the regulatory \& fiscal promotion of biofuels. COM; 547 final. Brussels: CEC; 2001.

European Commission. An EU strategy for biofuels. COM; 34 final. Brussels: Commission of the European Communities; 2006.

European Commission, DG for research/DG for energy and transport, hydrogen energy and fuel cells: a vision of our future. Final report of the high level group. Rep No. EUR 20719EN. Brussels; 2003.

United Nations Development Programme. World energy assessment: energy and the challenge of sustainability. New York; 2000.

Hammar H, Lofgren A, Sterner T. Political economy obstacles to fuel taxation. IAEE - The Energy Journal 2004;25(3):1-18.

IEA. Transport technologies and policies for energy security and $\mathrm{CO}_{2}$ reductions. Paris: IEA; 2003.

CEC. Draft directive on passenger car related taxes COM (05)261 (26714) 11067/05. Brussels; 2005.

IPCC. Climate change. IPCC third assessment report; 2001.

Clark ll WW, Paolucci E, Cooper J. Commercial development of energy environmentally sound technologies for the auto-industry: the case of fuel cells. Journal of Cleaner Production 2003:11(4):427-37.

OECD. Improving the environment through reducing subsidies, part I: summary and policy conclusions, and part II: analysis and overview of studies. Paris: OECD; 1998. 
European Environmental Agency. Environmental agreements - environmental effectiveness. Copenhagen: European Environment Agency; 1997. European Commission. Energy efficiency in the European community towards a strategy for the rational use of energy COM. European Commission; 1998. p. 246.

Maack MH, Skulason JB. Implementing the hydrogen economy. Journal of Cleaner Production 2006;14(1):52-64.
Thérèse Steenberghen has $\mathrm{a} \mathrm{PhD}$ in urban and regional science. She is managing director of the Spatial Applications Division, at the Catholic University of Leuven, Belgium. She is lecturer at the Geography Department.

Elena Lopez is PhD student and member of the research team of TRANSyT Centre for Transport Research at the Universidad Politécnica de Madrid. 